\title{
Representations of Muslims in English Renaissance Drama
}

\author{
Adel Alshammari \\ Department of English \\ University of Tennessee, Knoxville \\ Knoxville, TN, 37996 \\ United States
}

\begin{abstract}
This paper examines the representations of Muslim characters in Marlowe's The Jew of Malta, Shakespeare's Titus Andronicus, and Kyd's Soliman and Perseda. It also investigates the attitudes of English playwrights toward Muslims as well as the public sentiment that encourages these dramatists to present Muslim characters so negatively in drama.
\end{abstract}

Key words: Renaissance drama, Islam, Moor, Turk, Renaissance tragedy.

\section{Introduction}

Muslims and Islam had been deliberately vilified in English Renaissance tragedies. Hatred, contempt, and prejudice are what drove Christian writers to treat Muslims with hostility in drama, representing them in the most negative manner, a representation that is similar to, or perhaps worse than, that of Jews. The increasing animosity that Christian playwrights maintained toward Islam and its followers resulted in making false, exaggerated references to Muslims, too. Marlowe's The Jew of Malta, Shakespeare's Titus Andronicus, and Kyd's Soliman and Perseda are famous plays in which Muslim characters are presented as barbarously villain, lustful, and deceitful.

Muslims are represented by Moors or Turks in these three tragedies, since both groups were Muslims coming from territories controlled by an Islamic state. Yet, Abu-Baker states that Moors, who were originally black African descendants, seem to have been a more preferred reference to Muslims, especially in Marlowe's The Jew of Malta and Shakespeare's Titus Andronicus, as the white audience in that time perceived Moorish characters in their blackness as more pagan, lustful, treacherous, [and] barbarous" than Turks. (Abu Baker 124) White readers despised blackness, often conceiving it as the color of slaves, who were seen as inferior. Thus, choosing Moorish characters as representatives of Muslims is indicative of the writers' intention to portray them as slanderously as they could.

\section{The roots of the dispute between Christians and Muslims}

One might ask: why were Muslims treated so contemptuously in English Renaissance drama? Indeed, the deliberate misrepresentation of Muslims in drama stems from a Christian ideological disdain toward the religion of Islam since its emergence. Islam has become a religious force rivalling with Christianity since its birth. Speaking of politics between the two rivals, Marshall Baldwin remarks, in "Western Attitudes toward Islam," that "With the Muslim expansion across northern Africa and into Spain and France there began a persistent hostility which punctuated the diplomacy of the Mediterranean world for a thousand years." Islam is, moreover, "the only religion which, subsequent in time to Christianity, has taken from it large territories and inflicted upon it major military defeats" (403-4). Speaking particularly of the sixteenth and seventeenth century England, the Ottoman empire was the most feared and hated Muslim power to English Christians. Following its vastly continuous invasions of European territories, such as Serbia and Hungary, the Ottoman state became increasingly a source of threat to both Europe. According to Abu-Baker, "The threat was more real than historianshave often imagined, and by the first half of the seventeenth century no Englishman could ignore the threatening Turkish naval incursions on the south coastof England" (1). Thus, this vindictive depiction of Muslims in English Renaissance drama was not unexpected. It is no surprise to see the English playwrights misrepresent and villainize their rival enemy, as they essentially regarded this dramatic attack in their writings as a Christian doctrine and a religious commitment. AbuBaker notes that "It was in this spirit of religious hostility thatimaginative Christian Europeannarratives, from the Middle Ages on, deliberately sacrificed accuracy for thesake of constructing a negative image of Islam and Muslims that was relevant to the polemical purposes of their representations" (abstract).

\section{The depiction of Moors and Turks in Marlowe's The Jew of Malta}

Marlowe's The Jew of Malta is a well-known tragedy in which Muslims are portrayed as villainous, treacherous, savage invaders, and lustful creatures. From the very beginning of the play, Marlowe introduces Muslims, who are represented by Turks in his play, to the audience as thieves of either money or land. In Act I, the Turkish bashaw Selim Calymath shows up in Malta, demanding a tribute of ten years, a tribute that the governor of Malta Frenze 
describes as "overgreat" and backbreaking. Before the Turks demand the tribute, they remind the Maltese governor and his soldiers that they came from "Rhodes, From Cyprus, Candy, and those other isles,

That lie betwixt the Mediterranean seas," displaying their current domination over other Christian territories and demonstrating their reckless readiness to take over Malta if it does not succumb to their demands. (Marlowe 1.2.15) Turks are shown here to be the controlling despotic power, whereas the Christian Malta appears to be a peaceful, defenseless nation surviving at the mercy of the dictator Muslims. Moreover, Marlowe vilifies his Turkish and Moorish characters to the extent that he legitimizes enslaving them in return for their wickedness. When Bosco, a Spanish soldier, wins a naval fight with the Turks, he brings Turkish captives to sell them as slaves in Malta. Frenze welcomes him warmly, and he orders his soldiers to sell the Turks and "set them straight in show" so that others can see them all in their state of humiliation. He then breaks his alliance with the Turks, pledging his sword and the swords of Maltese soldiers to Bosco in his fight against the "barbarous, misbelieving Turks" (Marlowe 2.2.46).

Moors represent a more heinous version of Muslims in The Jew of Malta. In "The Popular Image of the Black Man in English Drama," Tokson points out that Moors are employed openly in English drama to represent Muslims as agents of evil. (4) In The Jew of Malta, in fact, Barabas's vindictive, spiteful plot in The Jew of Malta would not have taken place without the assistance of Ithamore, a Moorish slave who says he was "brought up in Arabia." Barabas purchases Ithamore to help him execute his schemes against Ferneze, as well as against all others who stand in his way. (Marlowe 2.3.132) When Barabas questions Ithamore about how he spent his time before he became a slave, Ithamore replies:

$>$ In setting Christian villages on fire,

$>$ Chaining of eunuchs, binding galley slaves.

$>$ One time I was an ostler in an inn,

$>$ And in the nighttime secretly would I steal

$>$ To travelers' chambers and there cut their throats.

$>$ Once at Jerusalem, where the pilgrims kneeled,

$>$ I strewed powder on the marble stones,

$>$ And therewithal their knees would rankleso

$>$ That I have laughed a-good to see the cripples

$>$ Go limping home to Christendom on stilts. (Marlowe 2. 3. 207-16)

Ithamore is introduced here as a Moorish man earning a living out of injuring his innocent Christians. Ithamore is also shown as a murderer and a thief who has no reluctance to steal, torture, burn, and kill his Christian victims. Barabas admires Ithamore's heinous acts, assuring him that they are "villains both," and they "hate Christians both" (Marlowe 2.3.218-19). It is Ithamore with whom the Jewish Barabas schemes to poison his daughter Abigail, who disapproves of her father's vindictive acts and consequently turns a Christian nun. Promised by Barabas to be free and be his heir, Ithamore carries the poison then murders Abigail in a nunnery: "Now shalt thou see the death of Abigail, That thou mayst freely live to be my heir" (Marlowe 3.4 63-64). Both the Jewish Barabas and Muslim Ithamore are depicted here to be two allies scheming against the guiltless Abigail for turning Christian. Moreover, before murdering Abigail, the two accomplices concoct a plan to make Lodowick, the governor's son, and Mathias, Lodowick's friend, get into a dispute over Abigail, their mutual beloved. What sparks the conflict between them is a forged letter written by Barabas but delivered by Ithamore to Mathias, in which Lodowick allegedly challenges him to a duel. Barabas and Ithamore's intrigue succeeds. And there occurred a fight between Lodowick and Mathias in which they eventually kill each other. (Marlowe 3.1-2. 318-20) Before Abigail dies, she confesses to the priest Bernardine her father's role in deceiving Mathias and Lodowick and dragging them into their fatal duel. (Marlowe 4.1.22-29) Barabas realizes that Abigail had confessed his crimes to Bernardine. To silence him, Barabas hatches a plan to murder Bernardine and frame Jacomo, another friar, for this crime. Again, it is Ithamore who executes Barabas's spiteful plans of murders. Showing neither mercy nor hesitation, Ithamore strangles Bernardine with a rope and murders him in a cold blood. (Marlowe 4.1.328-31)

Even more Machiavellian is Ithamore's betraying his master Barabas and committing a double villainy against the Maltese people and now his Jewish master. Tempted by the love of the courtesan Bellamira, Ithamore turns against Barabas and blackmails him, "Sweet Bellamira, would I had my master's wealth for thy sake!" (Marlowe 4.2. 6061). It is Barabas's secrets which leave him open to extortion by Ithamore, And Ithamore's treacherous persona unfolds vividly here as he breaks the promise that he has made to Barabas when they first met: "my name's Ithamore, my profession what you please" (Marlowe 2.3.169-70). When blackmailing Barabas fails, Ithamore exposes all their mutual secrets of murders and intrigues to the prostitute Bellamira, who later reveals those schemes to the governor. (Marlowe 4.2. 333) Ithamore appears here as a lustful fool thinking of nothing but to satisfy his sexual desire, even when it comes to exposing his own malice.

\section{Moors and Turks in Shakespeare's Titus Andronicus}


Shakespeare also employs an image of a despicable, corrupt, and lustful Moor in his Titus Andronicus. In fact, the tragic, bloody events permeating the play are caused by a number of conspiracies hatched between the adulterous

Tamora, the Queen of the Goths, who is a wife of Saturninus, her two sons, and her beloved Moorish Aaron, who takes sadistic pleasure in the most devious forms of villainy. All those conspirators are brought by Titus Andronicus, a Roman general, as captives when he comes back from a ten-year war with the Goths. Beside the Gothic Tamora and her sons, Aaron serves in this play as an alien enemy conniving against innocent Romans to exact undeserved revenge and ultimately get what he desires. When Tamora becomes Saturninus' wife and therefore the empress, Aaron, as her beloved, rejoices, thinking that it is time to get what he hopes for, "Then, Aaron, arm thy heart and fit thy thoughts / To mount aloft with thy imperial mistress." He also imagines that with Tamora becoming the empress of Rome, it is time to destroy the Roman nation, too, and see the "shipwreck" of "Rome's Saturnine" and the destruction of his "commonweal's" (Titus Andronicus 2.1.31).

Aaron's thoughts prove more heinous when he counsels Tamora's two sons Chiron and Demetrius to rape Lavinia, Titus' daughter, in the woods, where secrecy and privacy exist most: "There speak and strike, brave boys, and take your turns; There serve your lust, shadowed from Heaven's eye, And revel in Lavinia's treasury" (Titus Andronicus 2.1.34). It is also Aaron's idea that Lavinia "must lose her tongue" and that Chiron and Demetrius should "wash their hands in Bassianus' blood." Assisted by Aaron, the two brothers murder Bassianus, Saturninus' brother and Lavinia's husband, and rape Lavinia and cut off her hands and tongue. Moreover, plotting a dastardly revenge on Tirus, Aaron frames Titus' two sons Martius and Quintus for the murder of Bassianus, for which the brothers are arrested and taken for execution. (Titus Andronicus 2.3.37-45)

Through the image of the Moorish Aaron conspiring to murder Bassianus, and the dead Bassianus likened to "a slaughtered lamb," Shakespeare seemingly intensifies a stereotyped Christian notion that Muslims are misbelieving Christ-enemies existing to eliminate the Christian faith. (Titus Andronicus 2.3.42) Though a Christ-killer is a Jew in the Christian ideology, Aaron is represented as a Christ-killer, a fierce enemy of the Christian faith, while Bassianus is the innocent sacrificed Christian. What is evident here is that Shakespeare aligns Muslims with Jews in Titus Andronicus, showing them as one enemy preserving similar animosity toward Christianity and its followers. When Titus' other son Lucius captures Aaron and questions him, Aaron shows no regret in whichever crimes he has committed against the Romans. Instead, he takes pride in his malicious schemes: "I have done a thousand dreadful things As willingly as one would kill a fly; And nothing grieves me heartily indeed But that I cannot do ten thousand more" (Titus Andronicus 5.1.75).

\section{5. "Turning Turk"}

"Turning Turk" is famously another contemptuous expression that has been so often employed by English writers when describing treachery, mischief, or deception. "Turning Turk" originally means adopting Islam. Since a Turk in the Renaissance era was synonymous with a Muslim, to turn Turk meant to convert to Islam. However, conversion to Islam was still considered a treachery against the Christian faith. Therefore, the ones who turned Turk were considered traitors and were subject to divine damnation in Christianity. Such criminalization may have been reinforced by early modern Christians being preoccupied with fear and worries that a noticeable number of English Christians were converting to Islam. In "Turks and Jews in The Jew of Malta," Daniel Vitkus justifies the increasing number of converted Christians to Islam that the Islamic states, namely the Ottoman empire, at that time possesses what he describes as "the Islamic polity's absorptive capacity" (65). What Vitkus underlines here is that Islam accepted diversity, prohibited racial discrimination, and granted foreign residents a full access to trade and business during the Ottoman reign. Such political, commercial, and social tolerance and adaptability are what attracted non-Muslims to join Islam and abandon their religions and countries.

Over time, the phrase "Turning Turk" was popularized in its use that it referred to any form of treachery, in addition to its religious negative connotation. According to the Dictionary, to Turn Turk is "to become a Mohammedan: to go to the bad: to become hopelessly obstinate" (Davidson 1044).The terms can also be connected to any other form of failure, desertion, or abandonment. The phrase can be seen, for example, in Shakespeare's famous play Hamlet. In Act 3 Scene 2, when Hamlet becomes certain that Cladius had a role in murdering his father, he pledges that he will pursue vengeance on Cladius. However, he expresses his worries to Horatio that he may fail to revenge his father's death on Cladius, fearing that "the rest of my [Hamlet's] fortunes turn Turk" with him. (Hamlet 3.2.93) To turn Turk is a reference to Muslim that Shakespeare is employing in Hamlet in the context of the luck failing or betraying Hamlet. In a note about this expression, Henry Hudson confirms that it was common in Shakespeare's era to use "turning Turk" to indicate different types of treason or betrayal. "To Turn Turk with anyone," Hudson states, "was to desert or betray him, or turn traitor to him" (93).

\section{Muslims in Kyd's Soliman and Perseda}

Unlike Marlowe's The Jew of Malta and Shakespeare's Titus Andronicus, which include single Muslim characters being portrayed as individual villains, Kyd's Soliman and Perseda introduces a whole image of a villainous 
Turkish emperor ruling over a brutal Islam state. In Soliman and Perseda, Kyd proves more willing than Shakespeare and Marlowe to attack the Islamic world more directly. An evidence of Kyd's special hostility toward Muslims unfolds through the exaggerated religious language and false allusions he is using in this play.

"Koran" is cursed, "Mahomet" is referred to several times as Muslims' God, and Christ and Christendom are continuously aligned in a conflict with Muslims. In fact, the false references to Muslims and Islam prevalent in Soliman and Perseda indicate Kyd's intention to present to his audience a deformed version of Islam and Muslim, not a real one.

Soliman is described as a usurper, hypocrite, and a lustful and deceitful ruler in Soliman and Perseda. He also appears as a dictator maintaining readiness to exterminate all those who stand in his way. Representing his Christian enemies, Cyprus stands before Turkish soldiers, bravely reminding them that their Soliman "usurps in all that he possesseth." He also declares that Soliman does not believe in a true God. The only true God is who Christians worship, the one who will strengthen them against Soliman's "insolence," for which Cyprus is immediately slain by the Turkish invaders of the Rhodes. (Kyd 3.4.51) After the Turks seize power of the Rhodes, they force Christian captives to "turn Turk" or die. Here, Kyd, whether intentionally or ignorantly, dismisses the fact that forcing non-Muslim people to convert to Islam is prohibited in the religion. Forcibly converting others to Islam is condemned even in Quran, Muslims' holy book. And Kyd's depicting Muslims when forcing people to accept Islam apparently stems from an inclination to present Muslims as merely followers of a barbarous religion.

However, unlike men who receive death penalty for rejecting Islam, women are spared by Soliman and his soldiers. Captive Christian women are a source of sexual pleasure to the lustful Ottomans. The Ottoman leader Brusor preserves Christian women, deciding to present them as gifts to Soliman, which is "the greatest honor Fortune could afford" (Kyd 3.5.52). When Brusor presents Perseda and Lucina to Soliman, Soliman confirms that "This present pleaseth more than all the rest." Soliman then gives Lucina to Brusor and keeps Perseda as his own, wishing "That her captivity may turn to a bliss" (Kyd 4.1.56). After Soliman discovers that Perseda is Erastus' beloved, he decides to let her go, as Erastus is a Christian friend and ally of Soliman. However, unable to resist his lust and Perseda's beauty, the hypocrite Soliman becomes preoccupied with Perseda and thus decides to restore her by intrigue. With Soliman's approval, Erastus is framed for a crime and is consequently killed by Soliman's soldiers. Perseda is forcibly restored to Soliman, to which Soliman rejoices: "Here ends my dear Erastus' tragedy, ... And now begins my pleasant comedy" (Kyd 4.2.75).

\section{Conclusion}

In sum, it has been extremely biased the depiction of Muslims in English Renaissance tragedies. What is more disappointing is that the image of Muslims had been deliberately stained in well-known English tragedies such as Shakespeare's Titus Andronicus and Marlowe's The Jew of Malta. Represented by either Turks or Moors, Muslims are shown as agents of evil in Renaissance literature. All of Shakespeare, Marlowe, and Kyd misrepresent their Muslim characters, showing them as inconceivably lustful, barbarous, and villainous murderers and invaders. Such misrepresentation is argued to have sprung from a sense of Christian prejudice against Islam since its emergence almost fourteen hundred years ago. Scholars also argue that the expansion of the Ottoman empire, especially in the sixteenth and seventeenth centuries, caused a greater animosity in Christians toward Muslims. Indeed, the rivalry that the Islamic power has maintained with Christianity for the last thousand years is what encouraged Christian writers to attack Islam through the vilification of Moorish and Turkish characters in their pieces of writing.

\section{Works Cited}

Abu-Baker, Mohamed Hassan. "Representations of Islam and Muslims in Early Modern English

Drama from Marlowe to Massinger." Unpublished Thesis: University of Glasgow, 1997.

Baldwin, Marshall W. "Western Attitudes toward Islam." The Catholic Historical Review, vol. 27, no. 4, pp. 40311.

Davidson, Thomas. "Turn Turk." Chambers's Twentieth Century Dictionary of the English language, W. \&R. Chamers, 1903. ARCHIVE,

https://archive.org/details/chambersstwentie00daviiala/page/n3/mode/2up

Hudson, Henry N. Annotations. Hamlet, by William Shakespeare, Digi Reads, 2015, pp. 93.

Kyds, Thomas. The Tragedy of Soliman and Perseda. Benediction Classics, 2008.

Marlowe, Christopher. The Jew of Malta. English Renaissance Drama: A Norton Anthology, edited by David Bevington et al., W.W. Norton and Company, 2002, pp. 293-348.

Shakespeare, William. Titus Andronicus. Digi Reads, 2018.

Shakespeare, William. Hamlet. Digi Reads, 2015.

Tokson, Elliot H. "The Popular Image of the Black Man in English Drama1550-1688." G. K. Hall, Boston, 1982.

Vitkus, Daniel. "Turks and Jews in The Jew of Malta." Early Modern English Drama: A Critical Companion, edited by Garret A. Sullivan et al., Oxford University Press, 2006, 61-72. 